\title{
Mapping of Land Use Change in Grogol Sub-District Sukoharjo Regency in The Year 2007 and 2017
}

\author{
I Gulani $^{1}$, D R S Sumunar ${ }^{2}$ \\ Graduate School, Universitas Negeri Yogyakarta, Yogyakarta, Indonesia ${ }^{1,2}$ \\ indri.gulani2016@student.uny.ac.id $\left.{ }^{1}\right\}$
}

\begin{abstract}
Grogol sub-district is one of the districts in Sukoharjo Regency which is relatively fast development. Every development that occurs, both economic, social and cultural development is always associated with land use. This study aimed to determine the change of Land Use in Grogol Sub-district, Sukoharjo Regency in the Year of 2007 and 2017. The research type used in this research was descriptive research by using the collecting method and analysis of secondary data. Spatial analysis carried out in Land Use Change Mapping was to overlay two maps (Land Use in the Year of 2007 and Land Use in the Year of 2017) then produce a new map of analysis results (Land Use Change Mapping in the Year of 2007 and 2017). The results of this study indicate the use of land in Grogol subdistrict, Sukoharjo regency in the year of 2007 and 2017 experienced a very significant change, where the changes that occur are dominated by some rice fields converted to become wake-up land such as malls, shops, hotels, and settlements.
\end{abstract}

Keywords: Land Use Change, Spatial Analysis, New Urban Area

\section{Introduction}

The phenomenon that occurred in Indonesia shows that in the last ten years, the development of a city tends to bring new urban areas around the city area [1]. The development of a city cannot be avoided, both in the economic, social and cultural. The development of this city can show by the population growth and the increase of activity in it $[2]$.

According to Abd Rahman [3], land use is the final result of every form of human intervention to the land on the earth surface that is dynamic and serves to meet the needs of life both material and spiritual. Land as a unity of a fixed and limited number of natural resources can be damaged or decreased in the productivity of natural resources. Land is defined as a physical environment consisting of climate, relief, land, water, flora, fauna, and the form of human cultural results.

Grogol sub-district is one of the districts in Sukoharjo Regency which is relatively fast development. Every development that occurs, both the development of economics, social, and cultural almost always closely related to the use and utilization of land. The main factor supporting the development of Grogol Sub-district is the change of some rice fields that turn into residential land, industry, shops, offices, and hotels. The rapid development of Grogol 
sub-districts in both the economic, social and cultural fields has prompted researchers to analyze further and redevelop the potential of the land. In this case, that makes the Grogol district more crowded than the other districts in Sukoharjo district and makes Grogol district called Solo Baru.

Advances in remote sensing technology in data recording have been able to provide data in the form of a picture of an earth surface object that can be called a satellite image. Objects in the satellite image can be processed in such a way that can generate new information through image interpretation that can be integrated with the geographic information system. The purpose of integrating remote sensing and geographic information systems is to obtain accurate and well-mapped information so that the outgoing data can be utilized to the fullest extent possible. The development of remote sensing and geographic information systems supports the availability of spatial and up-to-date information. This is very useful in the management of natural resources, especially land resources.

\section{Literature review}

The land use classification consisted of 43 classes [4]. Lillesand and Kiefer [5] define Classification is performed using the method of visual interpretation (digitize on screen) on a scale of 1:2.500, with elemental approach that includes hue (related to the color/degree of grayness of an object), texture (frequency of change of hue), pattern (spatial arrangement of objects), size , forms (directly related to the general form, configuration or framework of a single object form), shadows and sites (the location of an object against other objects).

\section{Method}

\subsection{Objectives Of The Research Questions}

According to the background, this research will answer the following question: How The Changing of Land Use Change in Grogol Sub-district in 2007 and 2017.

This research is a research that uses a quantitative approach with data collection methods and secondary data analysis. This study was conducted to determine The Changing of Land Use Change in Grogol Sub-district in 2007 and 2017.

\subsection{Research Method}

This research is research that uses a quantitative approach. This study was conducted to determine The Changing of Land Use Change in Grogol Sub-district in 2007 and 2017. The analysis of the changing of land use was done by conducting Quickbird image analysis in 2007 and 2017. Classification is performed using the method of visual interpretation (digitize on screen) on a scale of 1:2.500, with The land use classification, consisted of 43 classes. The land use classification used refers to the Indonesian National Standard classification system 19-6728.3-2002. 


\section{Result and discussion}

\subsection{Land Use in $\mathbf{2 0 0 7}$}

In 2007, Grogol sub-district had a variety of land use types. The land use map of 2007 was made for comparison with the land use map of 2017. The most prominent land use in 2007 was technical irrigation rice fields with an area of 1425.73 ha or about $45 \%$ of Grogol's total area. The use of this land can also indicate community activity in the area, where the people of Grogol Sub-district look at as farmers.

Table 1. Land Use of 2007.

\begin{tabular}{cl} 
No & Land Use \\
\cline { 2 - 2 } 1 & Dense Settlements \\
3 & Sparse Settlements \\
4 & Sport Complex \\
5 & Cemetery \\
6 & Technical Irrigation Rice Field \\
7 & Mixed Garden \\
8 & Industry \\
9 & Terraced Forest Land \\
10 & Temporary Apical Land \\
11 & Bush \\
12 & Swamp \\
13 & Grass \\
14 & Field \\
15 & Building \\
16 & Lake \\
17 & Others (River and Rail Road) \\
\hline Source: Data Processing of 2018
\end{tabular}




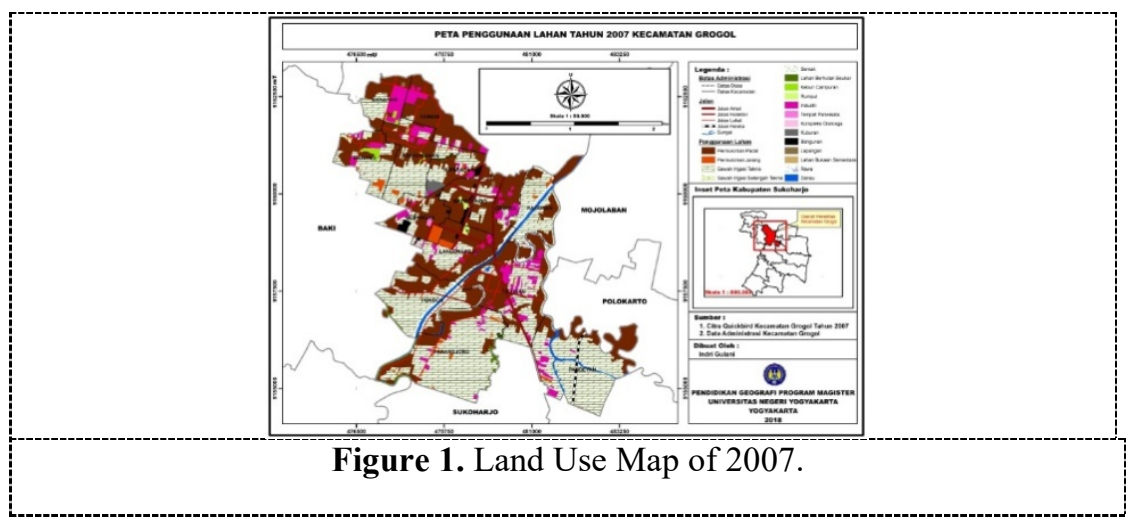

\subsection{Land Use in 2017}

The land use of 2017 in this study is referred to as the latest land use map. In the year of 2017, there were several different types of land use over the years (2007), where technical irrigation rice fields have decreased and this is due to some technical irrigation rice fields being converted as dense settlements and buildings. If in 2007 there were 17 types of land use, then in 2017 there were only 14 types of land use. Types of land use that are not in land use in 2017 are semi-technical irrigated rice fields, mixed gardens, and grasses.

Table 2. Land Use of 2017.

\begin{tabular}{cl} 
No & Land Use \\
\cline { 2 - 2 } 1 & Dense Settlements \\
2 & Sparse Settlements \\
3 & Sport Complex \\
4 & Cemetery \\
5 & Technical Irrigation Rice Field \\
6 & Industry \\
7 & Terraced Forest Land \\
8 & Temporary Apical Land \\
9 & Bush \\
10 & Swamp \\
11 & Field \\
12 & Building \\
13 & Lake \\
14 & Others (River and Rail Road) \\
15 & Dense Settlements \\
16 & Sparse Settlements \\
17 & Sport Complex \\
\hline
\end{tabular}

Source: Data Processing of 2018 


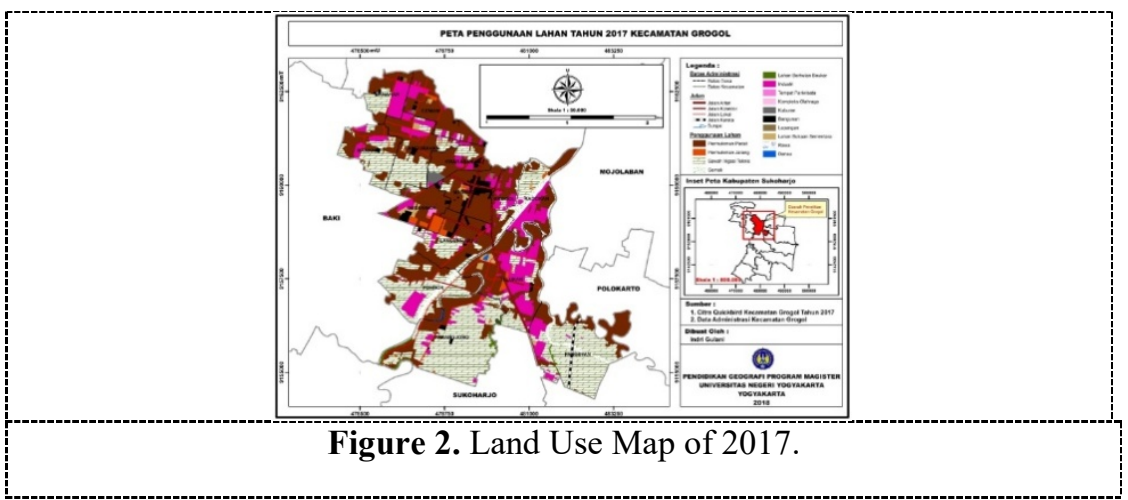

\subsection{The Change of Land Use in The Year 2007 and 2017}

The changing of land use can be interpreted as a changing process from the previous changing of land use to other permanent or temporary land use, and it is a logical consequence of the growth and transformation of changes in the socio-economic structure of a developing society. If land use changes into settlements or industries, then this changing of land use is permanent and irreversible, but if switching to plantations is usually only temporary.

Table 3.Some examples of Land Use change in the Year of 2007 and 2017

\begin{tabular}{llll}
\hline No & & Land Use in 2007 & Land Use in 2017 \\
\cline { 2 - 3 } 1 & Building & Industry \\
2 & Lake & Dense Settlements \\
3 & Lake & Temporary Apical Land \\
4 & Industry & Tourism Sites \\
5 & Mixed Garden & Building \\
6 & Cemetery & Industry \\
7 & Temporary Apical Land & Dense Settlements \\
8 & Field & Industry \\
9 & Field & Dense Settlements \\
10 & Sparse Settlements & Building \\
11 & Dense Settlements & Industry \\
12 & Swamp & Industry \\
13 & Grass & Industry \\
14 & Technical Irrigation Rice Field & Dense Settlements \\
15 & Bush & Industry \\
\hline
\end{tabular}


The table above shows the changes in land use that occurred in Grogol Sub-district within ten years, from 2007 and 2017. The dominant land use is dense settlements and irrigated rice fields. Both types of land use have a very small difference, where the use of densely settled land is $1276.93 \mathrm{Ha}$ or about $40 \%$ from Grogol Subdistrict total, while technical irrigation rice field is 1114.9 Ha or about $35 \%$ from Grogol Subdistrict total area.

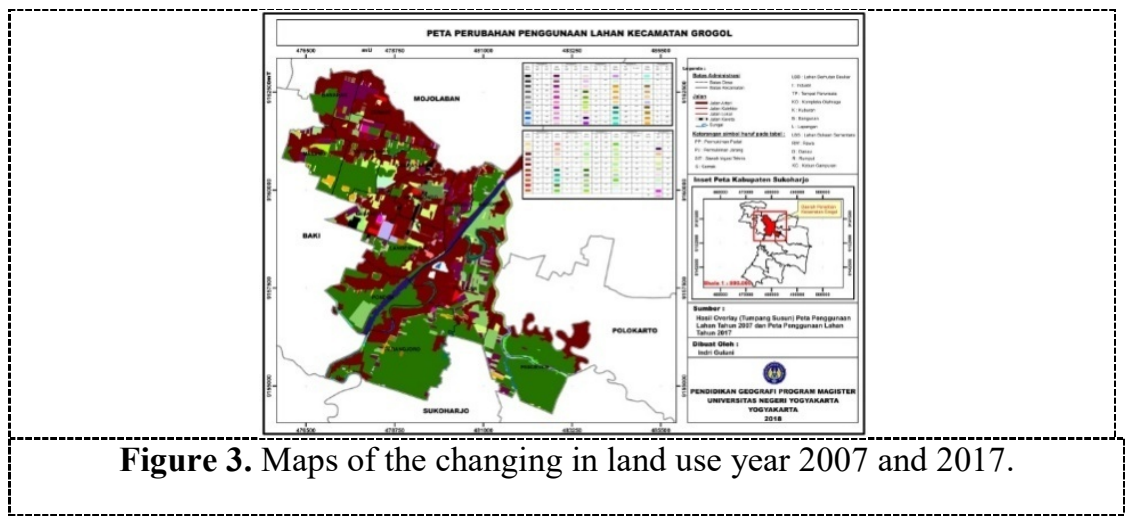

\section{Conclusion}

Land use that has decreased extensively in Grogol Subdistrict during ten years from 2007 and 2017 is $45 \%$ technical irrigation rice field, where the use of the land is converted into the use of building land, cemetery, temporary apical land, and dense settlements. The changing of land use that occurred dominated by the use of densely populated settlements, in this case, that makes Grogol Subdistrict more crowded and given the name as Solo Baru.

Acknowledgments. A great thanks to Mrs. Dyah Respati Suryo Sumunar who has given me the opportunity to write and be my collaborator in this research. Also, thanks to all who have helped me in writing this article.

\section{References}

[1] T. A. Dwiyanto and S. Sariffuddin, "Karakteristik Belanja Warga Pinggiran Kota (Studi Kasus: Kecamatan Banyumanik Kota Semarang)," J. Pengemb. Kota, vol. 1, no. 2, pp. 118-127, 2013.

[2] T. Firman, "The Continuity and Change Mega Urbanization in Indonesia," Habitat Int., vol. 33, no. 4, pp. 327-39, 2009.

[3] K. Lillesand, Remote Sensing and Image Interpretation. Yogyakarta: Gadjah Mada University Press, 1990.

[4] D. R. Putra and W. Pradoto, "Pola dan Faktor Perkembangan Pemanfaatan Lahan di Kecamatan Mranggen, Kabupaten Demak," J. Pengemb. Kota, vol. 4, no. 1, p. 67, Oct. 2016.

[5] T. Lillesand, R. W. Kiefer, and J. Chipman, Remote sensing and image interpretation. New York: John Wiley \& Sons, 2014. 